\title{
アノードレイヤ型ホールスラスタの作動特性*1 \\ Operating Characteristics of an Anode Layer Type Hall Thruster
}

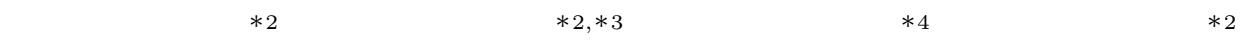 \\ Naoji Yamamoto, Takafumi NaKagawa, Kimiya Komurasaki and Yoshihiro Arakawa
}

Key Words : Electric Propulsion, Hall Thruster, Anode Layer, Hollow Anode

\begin{abstract}
Thrust performance and stable operation conditions of an anode layer type Hall thruster was investigated using a $1.5 \mathrm{~kW}$ class anode layer type Hall thruster. The thrust efficiency reached at $53 \%$ with the specific impulse of 2,000 s, which are competitive with these of SPT-100 thrusters. Anode shape and axial position of the anode were changed. Stability of the discharge was found sensitive to the anode configuration and applied magnetic flux density.
\end{abstract}

1. は じめに

ホールスラスタは,マグネティックレイヤ型とアノード レイヤ型の 2 種類に分類される ${ }^{1)}$. マグネティックレイヤ型 の特徵は加速チャンネル長さが加速チャンネル幅よりも長 く, チャンネル壁はセラミックで絶縁されている.一方ア ノードレイヤ型はチャンネル長さがチャンネル幅よりも短 く,チャンネル壁は導電体でできており，陰極電位に保た れている1).このチャンネル壁は磁極を守るためガードリ ングと呼ばれ，耐スパッタ性に優れた $\mathrm{C} / \mathrm{C} や S U S$ で作ら れており, 弚のためマグネティックレイヤ型よりも寿命は長 いと考えられている.チャンネル壁が陰極電位に保たれて いるために電子は壁と衝突せず陽極に向かい，陰極と陽極 の電位差は陽極近傍の薄い層に集中して現れる .この薄い 層はアノードレイヤと呼ばれ产の厚さは電子のサイクロト ロン半径のオーダーであり，イオンの加速はほとんどその 中で行われると考えられている.壁面との衝突による電子 のエネルギーロスがないため電子温度は高く22, 電離しに くい酸素やアルゴンでもある程度の性能か期待できる . ま た，例として同じパワーレベルのアノードレイヤ型スラス タ (D-55) とマグネティックレイヤ型スラスタ (SPT-100)

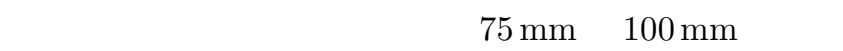
ノードレイヤ型のほうがサイズは一回り小さい3).これも衛 星に搭載する上で利点となる。一方, 安定な作動範囲が狭 いという欠点もある .この安定作動範囲を広げる指針を得 ることはアノードレイヤ型ホールスラスタ実用化のために 不可欠である .この作動安定性にホローアノード4) と呼ば れる陽極形状が寄与しているといわれている . またホロー アノードを使用することによって，陽極の過熱を防ぎ効率

\footnotetext{
*1 (C) 2003 日本航空宇宙学会

平成 14 年 10 月 28 日原稿受理

*2 東京大学大学院工学系研究科航空宇宙工学専攻

*3 現 三菱電機 (株)

*4 東京大学大学院新領域創成科学研究科先端エネルギー工学専攻
}

的な電離が得られるという報告もある ${ }^{3,4)}$. しかしこのホ ローアノード内部の物理に関してはまだわからないことが 多く，作動安定性との関係はわかっていない .

光こで本研究の目的は, $1.5 \mathrm{~kW}$ 級のアノードレイヤ型 ホールスラスタを製作し，关の推進性能を測定し性能を評 価することと，安定作動に陽極形状が与える影響を調べる ことである .さらに陽極形状の推進性能に及ぼす影響も調 べる.

\section{2. 実 験 装}

2.1 アノードレイヤ型ホールスラスタ 製作したアノー ドレイヤ型ホールスラスタ断面図及び回路图を第 1 図に示 す . 加速チャンネルの寸法は外径 $72 \mathrm{~mm}$, 内径 $48 \mathrm{~mm}$ で あり, 外径は $62 \mathrm{~mm}$ に変更可能である . スラスタ中心部の ソレノイドコイルと軟鉄で作られた磁極によって加速チャ ンネル内に半径方向の磁場が印加されており，コイルに流 す電流を変化させ, 加速チャンネル内に印加する磁束密度 の大きさを調整した，磁束密度の周方向分布を均一にする ためにソレノイドコイルは中心部のみに配置した ${ }^{5)}$. 磁束 密度の軸方向分布はスラスタ出口上流 $1 \mathrm{~mm}$ で最大になる ように設計されているが，陽極までは数ミリしかないため 加速チャンネル内では磁束密度の軸方向分布はほぼ一樣で ある.一方径方向には磁束は一定なので, 磁束密度は加速 チャンネルの内側壁面で最大となり，外側に行くに従い減 少するので, 本研究ではチャンネル壁面の中間点における 磁束密度を代表值として用いた . イオンによるスパッタリ ングから磁極を守るガードリングはステンレスでできてお り，陰極と結線され陰極電位に保たれている．ガードリン グと陽極の間には $1 \mathrm{~mm}$ の隙間がある . 陽極は内側と外側 の2つの環状リングで構成され，弚の間を推進剂が流れる ホローアノードとなっている．陽極の位置は $1 \mathrm{~mm}$ 間隔で 変えられる機構とした．また部品を交換することによって， ホローアノードの流路幅も変更できる . 推進剤にはキセノ ンを用いた . 


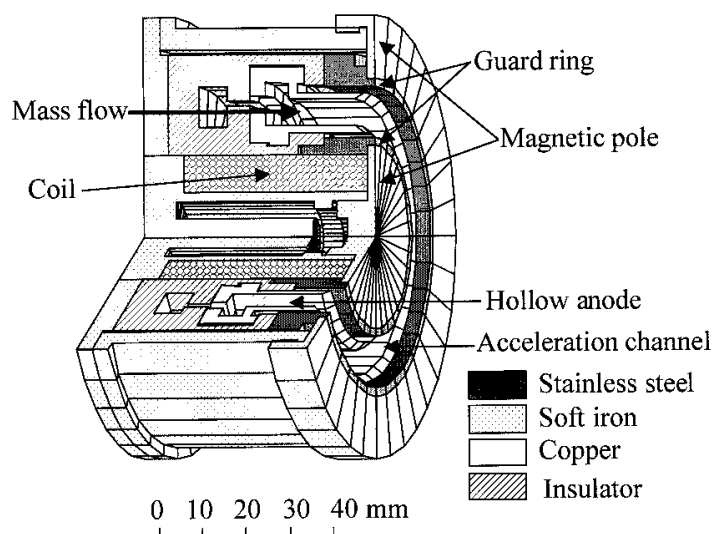

(a) 断面図

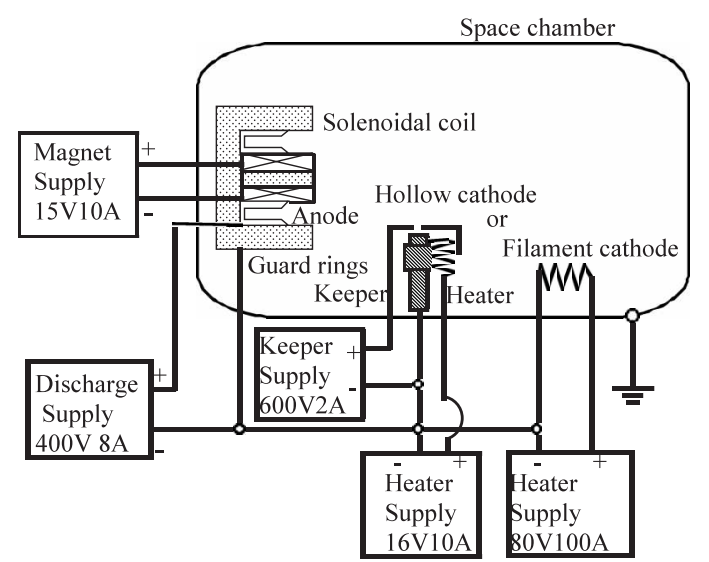

(b) 回路図

第1図 スラスタ断面図と回路図

陰極にはホローカソード（ION TECH 社製 HC252）を 使用した . 作動ガスにはキセノンを用い, 作動ガス流量 は $0.272 \mathrm{mg} / \mathrm{s}$ に固定した . しかし安定作動範囲を求める 実験においてはホローカソード光れ自身がノイズ源であ るために好ましくないので,, 7$)$, フィラメントカソード ( $\phi$ $0.45 \mathrm{~mm} \times 300 \mathrm{~mm} \mathrm{~L} \times 3 ， 2 \%$ thoriated tungsten）を用 いた 。

2.2 実験設備 スラスタの作動実験は直径 $2 \mathrm{~m}$, 長さ $3 \mathrm{~m}$ の真空チャンバで行った . 真空ポンプの排気速度は空 気で $3.0 \times 10^{4} l / \mathrm{s}$ であり, 到達圧力は $4.5 \times 10^{-4} \mathrm{~Pa}$ でス ラスタ作動時圧力は $7.3 \times 10^{-3} \mathrm{~Pa}$ 以下であった . 推力の 測定には振り子式スラストスタンド8) を用いた .このスラ ストスタンドの測定誤差は $1 \mathrm{mN}$ 以下に保たれた . イオン ビーム電流は直径 $5 \mathrm{~mm}$ のイオンコレクタをスラスタ中心 軸を含む平面上で一定半径 $500 \mathrm{~mm}$ の円弧状に掃引し，こ れを積分して求めた .

\section{3. 結果及び考察}

3.1 推進性能 推力の測定より比推力及び推進効率 $\eta_{\mathrm{t}}$ を見積り，イオンビーム電流の測定より以下の式で表され る推進阂利用効率 $\eta_{\mathrm{u}}$ と加速効率 $\eta_{\mathrm{a}}$ を見積もつた ${ }^{9)}$.

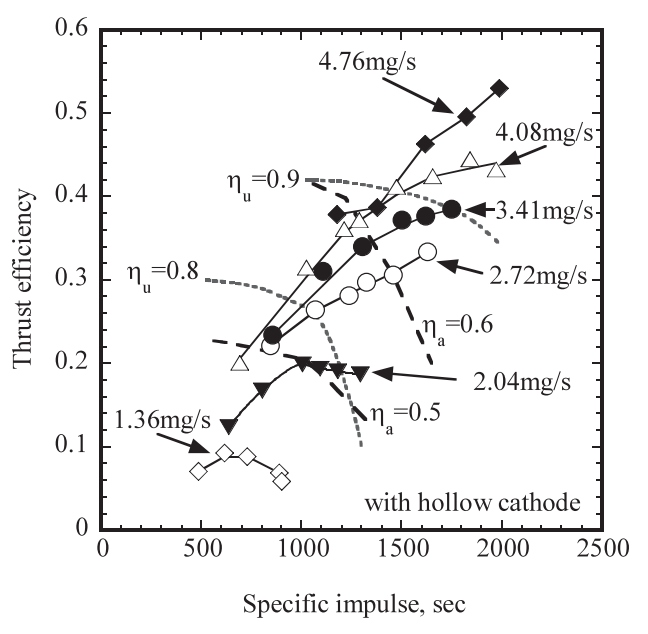

第 2 図 推進性能

第 1 表 スラスタの性能比較

\begin{tabular}{lcrr}
\hline & $\begin{array}{c}\text { Anode layer thruster } \\
\text { Univ. of Tokyo }\end{array}$ & PPS1350 & SPT-100 \\
\hline Power, W & 1,700 & 1,500 & 1,700 \\
Thrust, mN & 93 & 90 & 101 \\
$I_{\text {sp }}, \mathrm{s}$ & 1,900 & 1,740 & 1,840 \\
Thrust efficiency & 0.50 & 0.51 & 0.52 \\
\hline
\end{tabular}

$$
\begin{aligned}
& \eta_{\mathrm{t}}=\frac{F^{2}}{2 \dot{m} V_{\mathrm{d}} I_{\mathrm{d}}} \\
& \eta_{\mathrm{u}}=\frac{M I_{\mathrm{b}}}{e \dot{m}} \\
& \eta_{\mathrm{a}}=\frac{I_{\mathrm{b}}}{I_{\mathrm{d}}}
\end{aligned}
$$

ただし $M$ はイオン質量, $I_{\mathrm{b}}$ はイオンビーム電流, $e$ は素電 荷, $\dot{m}$ は推進剂の質量流量, $I_{\mathrm{d}}$ は放電電流を表している。

第 2 図にチャンネル外径 $72 \mathrm{~mm}$ での推進性能を示す.比 推力の増加に伴い, 推進効率は増加している.また推進昘流 量を増加させるに従い比推力及び推進効率は増加する . こ れらの主な要因は推進剂利用効率 $\eta_{\mathrm{u}}$ と加速効率 $\eta_{\mathrm{a}}$ の向上 によるものと思われる . 推進剂流量 $\dot{m}=4.76 \mathrm{mg} / \mathrm{s}$, 放電 電圧 $V_{\mathrm{d}}=350 \mathrm{~V}$ で効率は 0.53 ，このとき比推力は $2000 \mathrm{~s}$ を得た . 陰極流量 , 陰極消費電流 , コイル消費電力を考慮 に入れると，これは比推力 $1900 \mathrm{~s}$ ，効率 $50 \%$ となる.第1 表に代表的なマグネティックレイヤ型ホールスラスタでほ ぼ同じ出力である PPS1350 と SPT-100の $350 \mathrm{~V}$ での推 進性能を示す ${ }^{10,11)}$. 本スラスタはこれらのホールスラスタ と同等の性能が得られている．実験室の排気系の容量より $4.76 \mathrm{mg} / \mathrm{s}$ 以上の推進斉流量では実験は行わなかったが, 真 空チャンバの排気性能が向上すれば $\dot{m}$ のさらなる増加は 可能であると考えられる. しかし外径 $62 \mathrm{~mm}$ に変えて $\dot{m}$ を $3.40 \mathrm{mg} / \mathrm{s}$ 以上で作動させると, 磁束密度を増加させて も放電電流が抑制できなくなる現象が見られた .このよう に推進剤流量には上限が存在する．一方アノードレイヤ型 ホールスラスタである程度の性能が得られる推進斉流量密 度の下限は $0.136 \mathrm{mg} / \mathrm{s} / \mathrm{cm}^{2}$ といわれていることと比較す ると ${ }^{12)}$, 本スラスタの推進剂流量の下限は妥当である . 


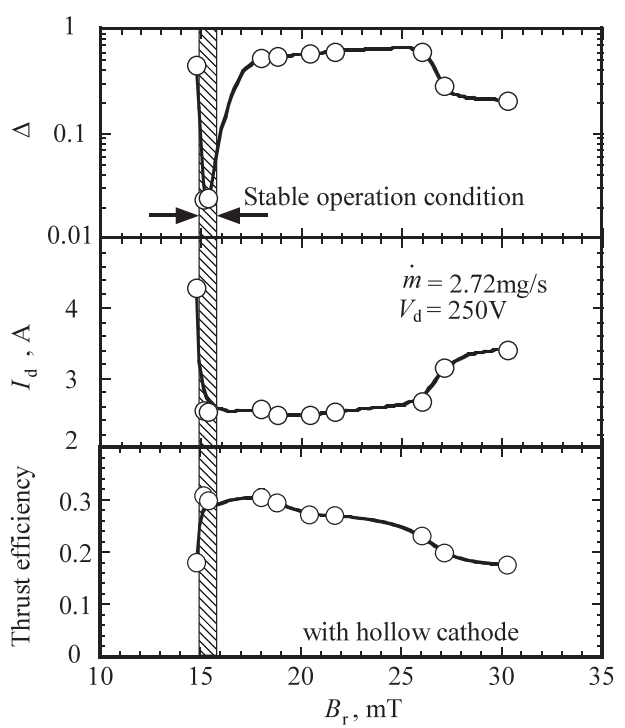

第 3 図＼cjkstart振動の大きさと放電電流と推進効率

3.2 安定作動範囲 振動の大きさを表す指標としては 以下の式で定義される指標 $\Delta$ を用いた . $\tau$ は測定時間で本 研究では $5 \mathrm{~ms}$ とした .

$$
\begin{gathered}
\Delta=\frac{\text { R.M.S }}{\bar{I}_{\mathrm{d}}}=\frac{1}{\bar{I}_{\mathrm{d}}} \sqrt{\frac{\int_{0}^{\tau}\left(I_{\mathrm{d}}-\bar{I}_{\mathrm{d}}\right)^{2}}{\tau}}, \\
\left(\bar{I}_{\mathrm{d}}=\frac{\int_{0}^{\tau} I_{\mathrm{d}}}{\tau}\right)
\end{gathered}
$$

振動が存在することと不安定であることは同意義ではな いが, 振動が成長して作動が停止することより, 振動の大 きさは安定性の指標となりうる7).

作動点を決める上で, 推進効率と共に安定性も重要な要 素である. 第 3 図に同じくチャンネル外径 $72 \mathrm{~mm}$ で加速 チャンネルに印加している半径方向磁場の磁束密度 $B_{\mathrm{r}}$ を 変化させたときの振動の大きさ $\Delta$ と放電電流と推進効率を 示す.アノードレイヤ型ホールスラスタの安定性は $B_{\mathrm{r}}$ に対 して非常に敏感で, 安定な $B_{\mathrm{r}}$ の範囲は非常に狭い． $B_{\mathrm{r}}$ が $18 \mathrm{mT}$ 近辺の幅 $1 \mathrm{mT}$ の作動範囲でのみ振動の大きさ $\Delta$ が 0.05 以下と抑えられている領域が存在する. $B_{\mathrm{r}}$ が $15 \mathrm{mT}$ 以下の低い範囲でも振動は抑えられるが, 放電電流が $6 \mathrm{~A}$ 以上流れ, 電子電流か増大するために加速効率が低下し， 推進効率が低下する.よって $B_{\mathrm{r}}=18 \mathrm{mT}$ 近辺の非常に狭 い作動範囲で作動させなければならない． $B_{\mathrm{r}}=20 \mathrm{mT}$ 印 加した状態では振動が大きくなるが, 放電電流が抑制され るため推進性能は最大となる .さらに $B_{\mathrm{r}}$ を増加させても， 放電電流はほとんど減少せず，また振動は激しくなり，推 力も低下するために推進効率は低下する .

さらに $B_{\mathrm{r}}$ を増加させると作動形態が遷移する .この条 件では $B_{\mathrm{r}}=32 \mathrm{mT}$ で遷移が起こり，この条件ではある程 度振動が抑えられているが, 放電電流が増加し, 性能は低 下する .これは低い $B_{\mathrm{r}}$ での作動ではみられなかった周波数

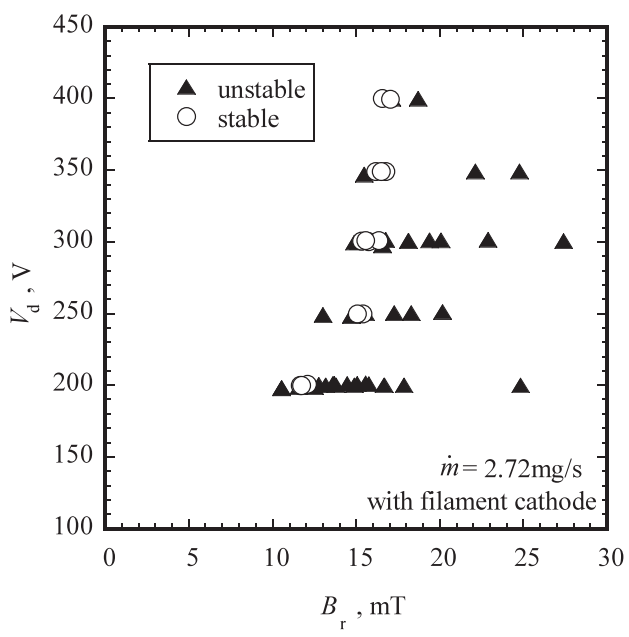

第 4 图 放電電圧と安定作動領域

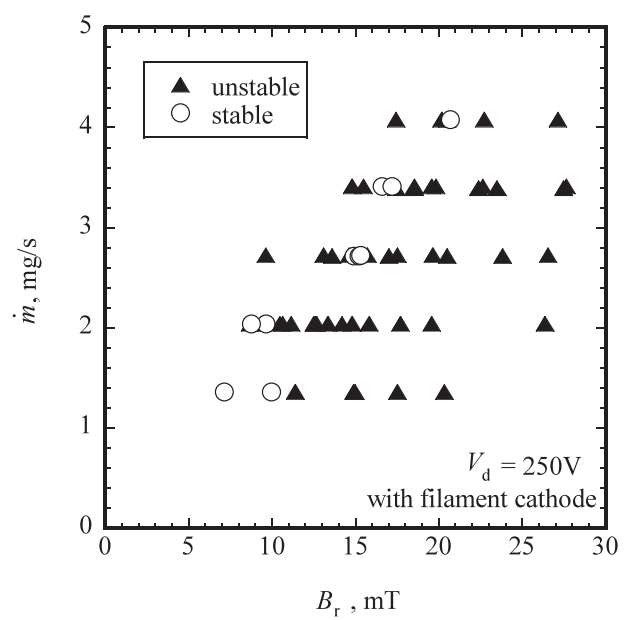

第 5 図 推進斉流量と安定作動領域

数 $\mathrm{MHz}$ のプラズマ振動か現れ, 兴の影響で電子の拡散が促 進したためと考えられる ${ }^{13)} . \dot{m}$ を減少させるなど作動条件 を変えると，この遷移が起こらずに作動が停止する．この ように作動に適した $B_{\mathrm{r}}$ の範囲は非常に狭い．安定な $B_{\mathrm{r}}$ の 範囲は, $\dot{m} や V_{\mathrm{d}}$, 加速チャンネル形状によって変わること が示唆されている7). 弚こで $\dot{m}=2.72 \mathrm{mg} / \mathrm{s}$ に固定して $V_{\mathrm{d}}$ と $B_{\mathrm{r}}$ を変化させたときの作動状態を第 4 図に, $V_{\mathrm{d}}=250 \mathrm{~V}$ に固定して $\dot{m}$ と $B_{\mathrm{r}}$ を変化させたときの作動状態を第 5 図 に示す . ○は振動の大きさ $\Delta$ が 0.05 以下の作動点 , $\Delta$ は 振動の大きさ $\Delta$ が 0.05 以上の作動点を示す . モデルが示 唆する通り, $\dot{m}$ を増加させるに伴い安定な $B_{\mathrm{r}}$ は増加する また $V_{\mathrm{d}}$ を増加させると安定な $B_{\mathrm{r}}$ は変化する .

3.3 ホローアノード形状と安定性 第 6 図に示すよう に陽極とガードリング間の距離を $1 \mathrm{~mm}$ に保ったまま陽極 位置及び陽極流路幅を変え, 关れ光れの形状ごとに振動の 大きさを測定し比較した . 以下では陽極位置を陽極先端と チャンネル出口の距離 $Z$ で表すこととする . また陽極流路 幅を第 6 図のように $D$ と定義する . ホローアノードの形状 を保ちながら $D$ と $Z$ を変えることができるように，加速 チャンネル外径を $62 \mathrm{~mm}$ に変更した . 


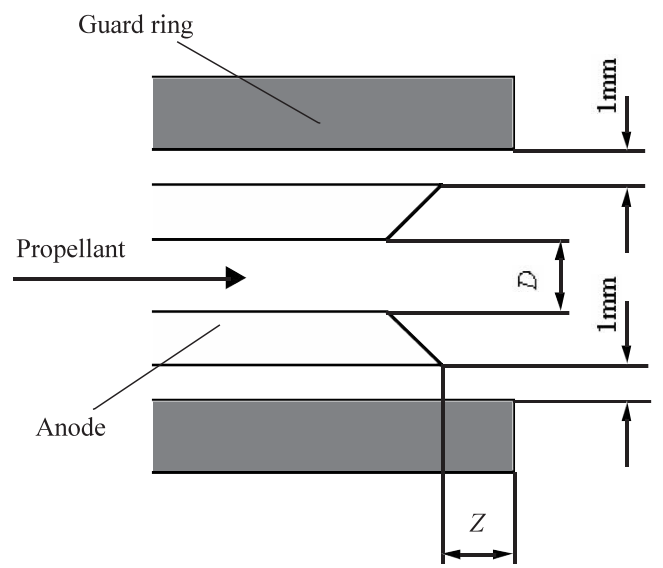

第 6 図 陽極部拡大図

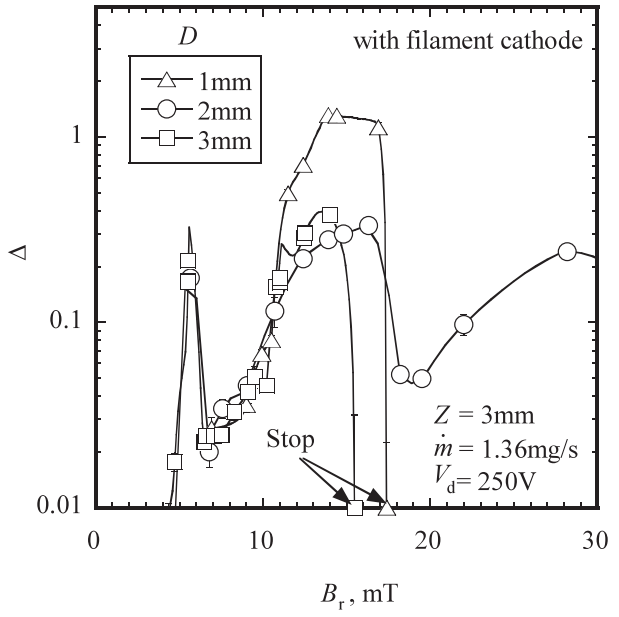

第 7 図＼cjkstart陽極流路幅と振動の大きさ

3.3 .1 陽極流路幅の影響 $V_{\mathrm{d}}=250 \mathrm{~V}, \dot{m}=1.36 \mathrm{mg} / \mathrm{s}$, $Z=3 \mathrm{~mm}$ に固定し $D$ を変えて安定性がどのように変化す るのか調べた . $D$ を変えたときの振動の大きさと放電電流 を乥れ光れ第 7 図，第 8 図に示す．安定な作動範囲は $D$ を変えても光れほど変わらない．また $B_{\mathrm{r}}$ が $10 \mathrm{mT}$ 以上 の大きい作動点では他と比較して $D=1 \mathrm{~mm}$ では振動が大 きく不安定になっていることがわかる . $D=1 \mathrm{~mm}$ の放電 電流は $D=2 \mathrm{~mm}, D=3 \mathrm{~mm}$ と比較すると放電電流は大 きい.また $D=1 \mathrm{~mm}, D=3 \mathrm{~mm}$ では $B_{\mathrm{r}}$ を大きくしてい くとある $B_{\mathrm{r}}$ で作動が停止してしまうが， $D=2 \mathrm{~mm}$ では $B_{\mathrm{r}}=16 \mathrm{mT}$ で振動は抑制されるが放電電流は増加する作 動形態に変わる. $D=2 \mathrm{~mm}$ では作動停止が起きないとい う観点から他と比較して安定であるといえる．

第 9 図に $D$ を変えたときの推進性能を示す. 安定かつ放 電電流が最小になるように $B_{\mathrm{r}}$ を選んだ . $D=2 \mathrm{~mm}$ では 推力が大きく，放電電流が少ないため最も推進性能がいい．

安定性や推進性能にはホローアノード内でのプラズマ生 成領域の広がり，及び乥れに付随する電子電流の陽極への 流入面積が大きく影響すると考えられる ${ }^{1)}$. これらが $D に$ よって変わるために安定性や推進性能に違いが生じたと思 われる。

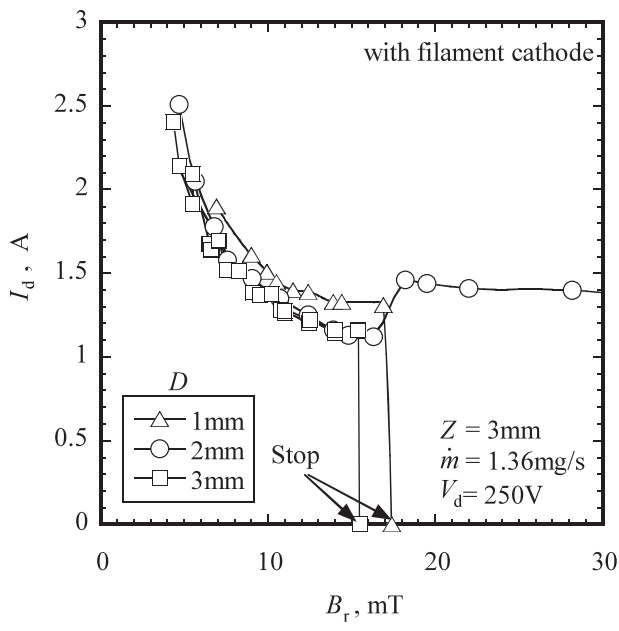

第 8 図＼cjkstart陽極流路幅と放電電流

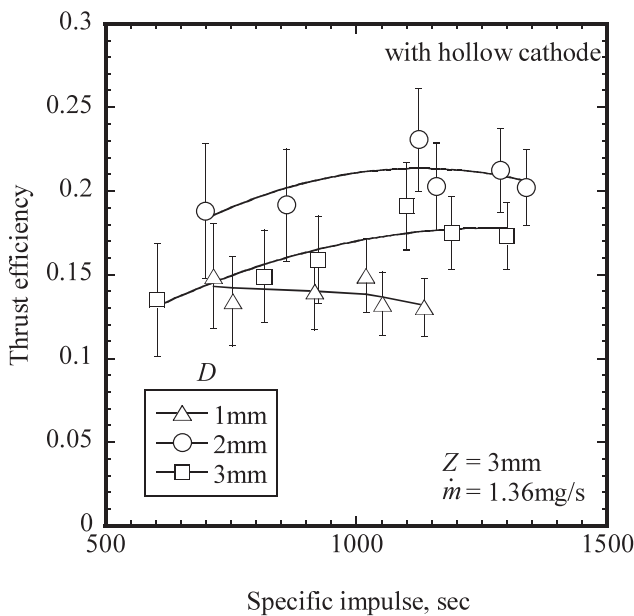

第 9 図＼cjkstart陽極流路幅と推進性能

3.3 .2 陽極位置の影響 $V_{\mathrm{d}}=250 \mathrm{~V}, \dot{m}=1.36 \mathrm{mg} / \mathrm{s}$ ， $D=2 \mathrm{~mm}$ に固定し，陽極位置 $Z$ を変化させたときの振 動の大きさと放電電流を乥れ艺れ第 10 图，第 11 図に示す. $Z=1 \mathrm{~mm}, 2 \mathrm{~mm}$ では振動の大きさ $\Delta$ が 0.05 以下の安定 作動点はない . また $Z=4 \mathrm{~mm}$ では, $B_{\mathrm{r}}$ が $5 \sim 10 \mathrm{mT}$ にあ る安定作動範囲は $Z=3 \mathrm{~mm}$ よりも狭い. しかし $Z=4 \mathrm{~mm}$ では $B_{\mathrm{r}}=14 \mathrm{mT}$ に安定作動点が存在する .この $B_{\mathrm{r}}$ の大き い安定作動点はいつも存在するとは限らず $V_{\mathrm{d}}, \dot{m}$ などに よる.また $Z=4 \mathrm{~mm}$ では $B_{\mathrm{r}}=15 \mathrm{mT}$ で $Z=1 \mathrm{~mm}$ では $B_{\mathrm{r}}=23 \mathrm{mT}$ で作動が停止するが , $Z=2 \mathrm{~mm}, Z=3 \mathrm{~mm}$ では作動状態が遷移し，第 3 図と同樣にこの遷移ののち振 動は抑制されるが放電電流は増加する .

放電電流は $Z$ を増加させる，すなわち陽極位置を上流側 に動かすごとに減少している。

第 12 図に $\dot{m}=1.36 \mathrm{mg} / \mathrm{s}, D=2 \mathrm{~mm}$ に固定して,$Z$ を変化させたときの推進性能を示す． $B_{\mathrm{r}}$ は作動が安定で $I_{\mathrm{d}}$ が最小になるように設定した . $Z=2 \mathrm{~mm}$ は $Z=3 \mathrm{~mm}$ ， $Z=4 \mathrm{~mm}$ と比較すると推進性能は低い．これは推力が低 く, $I_{\mathrm{d}}$ が大きいためである.このように $Z$ の最適值が存在 するのはマグネティックレイヤ型と同樣の理由によるもの 


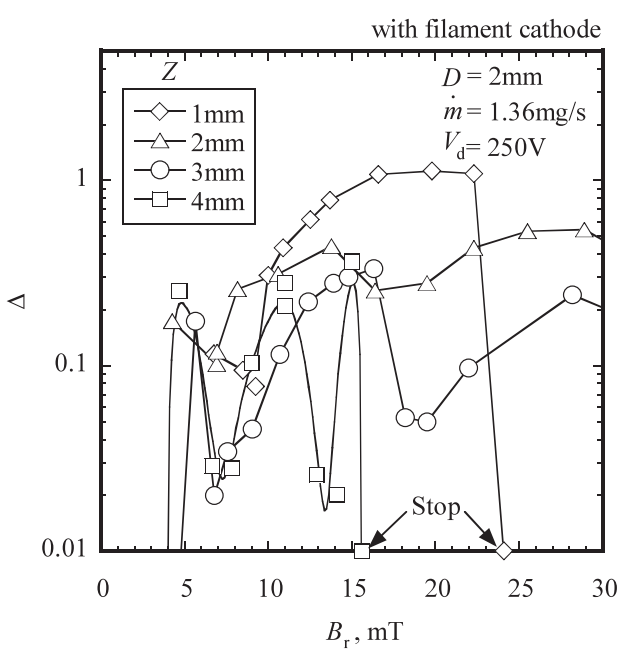

第 10 図陽極位置と振動の大きさ

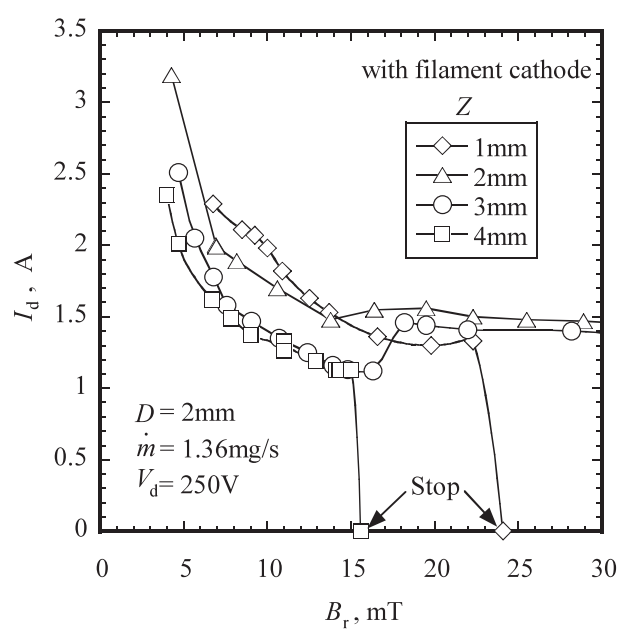

第 11 図 陽極位置と放電電流

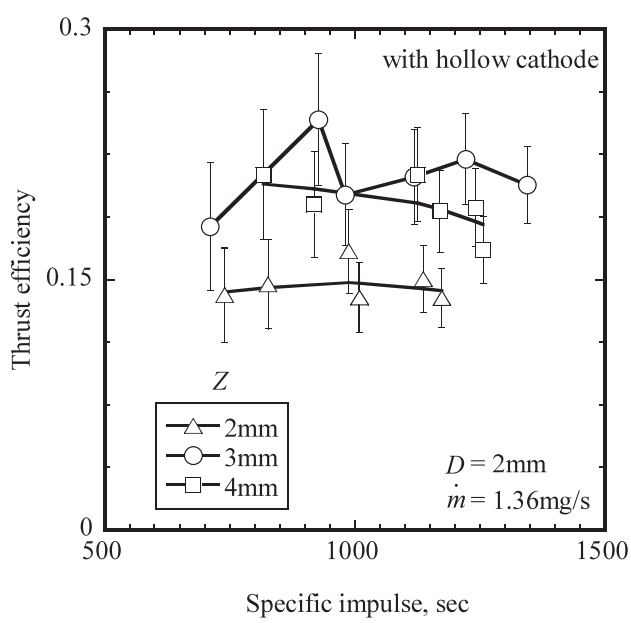

第 12 図陽極位置と推進性能

\section{と思われる14,15).}

3.3.3 陽極形状と安定作動 陽極形状が安定作動範囲に 及ぼす影響をまとめるために $\dot{m}=1.36 \mathrm{mg} / \mathrm{s}$ に固定し陽極 形状すなわち陽極流路幅 $D$ と陽極位置 $Z$ を变化させた . 安
第 2 表 スラスタ安定作動磁束密度範囲 $\left(V_{\mathrm{d}}=200 \mathrm{~V}\right), B_{\mathrm{r}}, \mathrm{mT}$

\begin{tabular}{ccccc}
\hline \multirow{2}{*}{$D$} & \multicolumn{4}{c}{$Z$} \\
\cline { 2 - 5 } & $1 \mathrm{~mm}$ & $2 \mathrm{~mm}$ & $3 \mathrm{~mm}$ & $4 \mathrm{~mm}$ \\
\hline $1 \mathrm{~mm}$ & - & - & $\leqq 8$ & $7 \sim 10$ \\
& & & $\leqq 14$ & $\leqq 14$, \\
$2 \mathrm{~mm}$ & - & - & $16 \sim 19$ \\
& & & & $\leqq 12$, \\
$3 \mathrm{~mm}$ & $\leqq 5$ & $\leqq 6$ & $7 \sim 13$ & $14 \sim 16$ \\
\hline
\end{tabular}

第 3 表 スラスタ安定作動磁束密度範囲 $\left(V_{\mathrm{d}}=250 \mathrm{~V}\right), B_{\mathrm{r}}, \mathrm{mT}$

\begin{tabular}{ccccc}
\hline \multirow{2}{*}{$D$} & \multicolumn{4}{c}{$Z$} \\
\cline { 2 - 5 } & $1 \mathrm{~mm}$ & $2 \mathrm{~mm}$ & $3 \mathrm{~mm}$ & $4 \mathrm{~mm}$ \\
\hline $1 \mathrm{~mm}$ & - & - & $7 \sim 10$ & $7 \sim 8$ \\
& & & & $\leqq 4$, \\
\multirow{2}{*}{$2 \mathrm{~mm}$} & - & - & $\leqq 5$, & $6 \sim 9$, \\
& & & $7 \sim 10$ & $13 \sim 14$ \\
& & & $\leqq 5$, & $\leqq 4$, \\
$3 \mathrm{~mm}$ & - & $\leqq 7$ & $6 \sim 10$ & $7 \sim 10$ \\
\hline
\end{tabular}

第 4 表 スラスタ安定作動磁束密度範囲 $\left(V_{\mathrm{d}}=300 \mathrm{~V}\right), B_{\mathrm{r}}, \mathrm{mT}$

\begin{tabular}{ccccc}
\hline \multirow{2}{*}{$D$} & \multicolumn{4}{c}{$Z$} \\
\cline { 2 - 5 } & $1 \mathrm{~mm}$ & $2 \mathrm{~mm}$ & $3 \mathrm{~mm}$ & $4 \mathrm{~mm}$ \\
\hline $1 \mathrm{~mm}$ & - & - & $\leqq 8$ & $\leqq 8$ \\
& & $\leqq 6$, & $\leqq 9$ & $\leqq 9$, \\
$2 \mathrm{~mm}$ & - & $7 \sim 8$ & $\leqq$ & $14 \sim 15$ \\
& & $\leqq 7$ & $\leqq 8$ & $7 \sim 9$ \\
\hline
\end{tabular}

定作動点の判断基準は $\Delta \leqq 0.05$ とした . また $B_{\mathrm{r}}$ の小さ い作動範囲に安定な作動領域が存在したが, 放電電流が大 きく加速効率が低下し推進効率が低下するためこのような 作動点は現実的でなく考慮しなかった。

第 2 表に $V_{\mathrm{d}}=200 \mathrm{~V}$ ，第 3 表に $V_{\mathrm{d}}=250 \mathrm{~V}$ ，第 4 表に $V_{\mathrm{d}}=300 \mathrm{~V}$ での安定に作動する $B_{\mathrm{r}}$ の範囲を示す .—は安定 作動がないことを表す.$D$ と $Z$ を変化させることにより安 定作動範囲は変化している. $D$ 力狭く， $Z$ の小さい $D 1 Z 1$, $D 2 Z 1 ， D 1 Z 2$ ではこれらの $V_{\mathrm{d}}$ の作動範囲では振動の小 さい安定作動点は見られなかった $. V_{\mathrm{d}}=100 \mathrm{~V}$ ではこれら の陽極形状でも安定作動点は存在した . また $V_{\mathrm{d}}=350 \mathrm{~V}$, $400 \mathrm{~V}$ での安定作動範囲は $300 \mathrm{~V}$ での安定作動範囲とほぼ 同じであった .

$Z$ が $3 \mathrm{~mm}$ より大きな陽極形状では $D$ によらず安定作動 範囲は存在している.乥こでホローアノードの効果を調べる ために, $\phi 1 \mathrm{~mm}$ の小孔が 36 個開いた円柱陽極を $Z=3 \mathrm{~mm}$ に設置して作動させたが，安定作動を得ることができなかっ た.これよりホローアノードが安定性に影響を及ぼしている ことか確認された . また $D=1 \mathrm{~mm}$ では $Z=3 \mathrm{~mm}, 4 \mathrm{~mm}$ で安定作動点が存在するが, 第 8 図 $(Z=3 \mathrm{~mm})$ と同樣 に $D 1 Z 4$ でも $D 2 Z 4 ， D 3 Z 4$ と比較すると放電電流が大き く,第 9 图と同樣に推進効率は低い. しかし $D=2 \mathrm{~mm}$ と $D=3 \mathrm{~mm}$ では推進性能のよい安定作動範囲に光れほど差 異は見られなかった . 


\section{4. ま と め}

アノードレイヤ型ホールスラスタを製作し安定作動に成 功した .アノードレイヤ型ホールスラスタの安定性は磁束 密度の変化に対して敏感であった . また推進性能を測定し

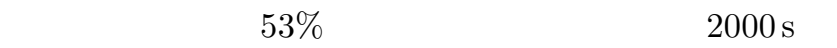
あった .これは同出力のマグネティックレイヤ型ホールス ラスタ SPT-100 の性能と比肩できるものである . アノー ドレイヤ型ホールスラスタの安定性にはホローアノードが 寄与しており, さらにこのホローアノードの形状 (軸方向 位置・陽極流路幅) が, 放電安定性及び推進性能に影響を 及ぼしている．特に陽極位置に関して敏感であることがわ かった.

\section{参 考 文 献}

1) Zhurin, V. V., Kaufman, H. R. and Robinson, R. S.: Physics of Closed Drift Thrusters, Plasma Sources Sci. Technol., 8 (1999), pp. R1-R20.

2) Choueiri, E. Y.: Fundamental Difference between the Two Hall Thruster Variants, Phys. Plasmas, 8, 11 (2001), pp. 5025-5033.

3) Garner, C. E., Brophy, J. R., Polk, J. E., Semenkin, A. V., Garlusha, V. I., Tverdokhlebov, S. O. and Marrese, C.: Experimental Evaluation of Russian Anode Layer Thrusters, AIAA Paper 94-3010, 1994.

4) Semenkin, A., Kochergin, A., Garkusha, V., Chislov, G., Rusakov, A., Tverdokhlebov, S. and Sota, C.: RHETT/EPDM Flight Anode Layer Thruster Development,
IEPC Paper 97-106, 1997 .

5) 柿本英明 : アノードレイヤー型ホールスラスタのプラズマ特性, 東京大学大学院修士論文, 2000 .

6）西山和孝, 清水幸夫, 舟木一幸, 国中 均, 都木恭一郎 : マイク 口波放電型中和器とホローカソードからの電磁杂隹音, 日本航空宇 宙学会論文集 , 49 (2001), pp. 84-91.

7) Yamamoto, N., Nakagawa, T., Komurasaki, K. and Arakawa, Y.: Extending Stable Operation Range in Hall Thrusters, AIAA Paper 02-3953, 2002.

8) Sasoh, A. and Arakawa, Y.: A High Resolution Thrust Stand for Ground Tests of Low-Thrust Space Propulsion Devices, Rev. Sci. Instrum., 64 (1993), pp. 719-723.

9) Komurasaki, K. and Arakawa, Y.: Hall-Current Ion Thruster Performance, J. Propul. Power, 8 (1992), pp. 1212-1216.

10) Gopantchuk, V., Kozubsky, K., Maslennikov, N. and Pridannikov, S.: Performance of Stationary Plasma Thruster PPS1350 and Its Qualification Status in Russia, IEPC Paper 99-086, 1999

11) Brophy, J. R.: Stationary Plasma Thruster Evaluation in Russia, Summary Report, JPL Publication 92-4, 1992.

12) Semenkin, A. V., Tverdokhlebov, S. O., Garlusha, V. I., Kochergin, A. V., Chislov, G. O., Shumkin, B. V., Solodukhin, A. E. and Zakharenkov, L. E.: Operating Envelops of Thrusters with Anode Layer, IEPC Paper 2001-013, 2001.

13) Yamamoto, N., Nakagawa, T., Komurasaki, K. and Arakawa, Y.: Discharge Plasma Fluctuations in Hall Thrusters, Vacuum, 65 (2002), pp. 375-381.

14) Kim, V.: Main Physical Feature and Processes Determining the Performance of Stationary Plasma Thrusters, J. Propul. Power, 14 (1998), pp. 736-743.

15) Kusamoto, D., Mikami, K. and Komurasaki, K.: Channel Length and Thruster Performance of Hall Thrusters, AIAA Paper 96-3194, 1996. 